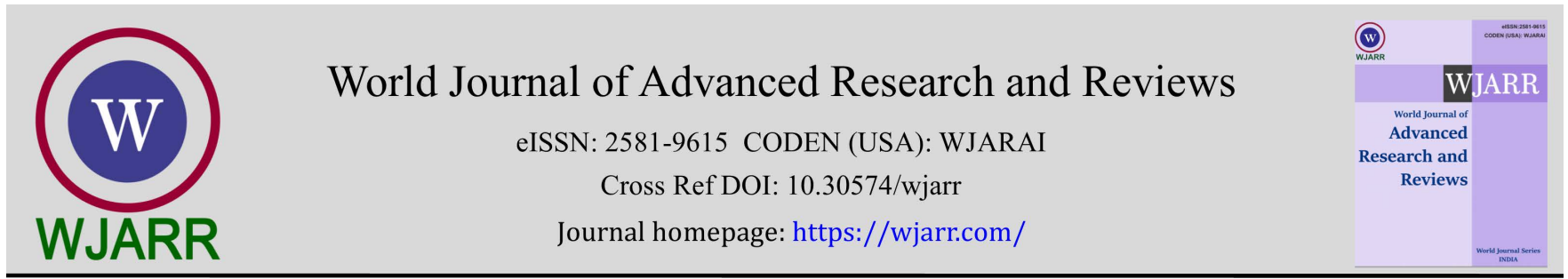

(RESEARCH ARTiCle)

Check for updates

\title{
Impact of corporate board and external audit attributes on earnings quality: Experience from Nigeria quoted foods and beverages firms
}

\author{
Oladejo M.O 1, Akintunde A.O 1, Yinus S.O ${ }^{3,}{ }^{*}$, Akanbi T.A ${ }^{1}$ and Olowokere J.K ${ }^{2}$ \\ ${ }^{1}$ Department of Management and Accounting, Faculty of Management Sciences, Ladoke Akintola University of Technology \\ Ogbomoso. \\ 2 Department of Accounting, Faculty of Management Sciences Osun State University, Oyo State, Nigeria. \\ ${ }^{3}$ Department of Accounting, Faculty of Management Sciences Ladoke Akintola University of Technology Ogbomoso, Open \\ and Distance Learning Centre. Oyo State, Nigeria.
}

World Journal of Advanced Research and Reviews, 2021, 12(03), 612-623

Publication history: Received on 21 November 2021; revised on 28 December 2021; accepted on 30 December 2021

Article DOI: https://doi.org/10.30574/wjarr.2021.12.3.0730

\begin{abstract}
The recent audit failures has pointed to weaknesses in financial report and give occasion of doubt to users about the reliability of earnings declared by firms. This study examines the effects of corporate board and external audit attributes on earnings quality of listed foods and beverages firms in Nigeria. Secondary data were employed through audited annual reports and accounts of eight (8) selected foods and beverages firms listed on the Nigerian Stock Exchange using judgmental sampling technique. Data collected were analyse using descriptive statistics like table, percentage and inferential statistics such as panel regression analysis. All Analysis were tested at $5 \%$ level of significance. The results revealed that audit firm size $(\beta=14485.32, P=0.000)$ which is external audit attribute and board size $(\beta=-2741.887$, $P=0.000)$, audit committee presence $(\beta=-8225.11, P=0.044)$ and company size $(\beta=5454.20, P=0.000)$ were the significant determinants of external audit and corporate board attributes of listed foods and beverages firms in Nigeria. Also, the result of panel regression revealed that audit independence $(\beta=-6.57 \mathrm{e}-06, \mathrm{P}=0.035)$ and audit firm size $(\beta=0.1141479, P=0.018)$ were the external audit attributes that had significant effect on discretionary accruals. The study therefore concluded that corporate board attributes (audit committee) and external audit attributes (auditor independence, audit firm size) had significant effect on earnings quality as measured by earnings management of selected foods and beverages firms in Nigeria. The study recommends that in order to enhance auditor's independence, uniform audit fee should be formulated, and also, disclosure should be made on other corporate board attributes like board members' year of experience and gender and for effective monitoring system.
\end{abstract}

Keywords: Earnings Management; Food and Beverages Firm; Audit Quality Attributes; Earning Quality; Discretionary Accruals

\section{Introduction}

The quality a firm's earnings serves as a guide to investment and such should be taken serious by accountants, preparers of financial statements auditors and other players in commerce. Most studies in accounting and auditing have been extensively on external audit attributes as determining the earnings quality of firms. However, studies on corporate board characteristics have been found impacting on earnings management. For instance, Kao and Chen, (2004) observed that under proper corporate governance mechanism, the board of directors might be able to monitor the firm and prevent the management from engaging in earnings management. Also, Kajola et al (2020) observed that board

\footnotetext{
* Corresponding author: Yinus SO

Department of Accounting, Faculty of Management Sciences Ladoke Akintola University of Technology Ogbomoso,Open and Distance Learning Centre. Oyo State, Nigeria.

Copyright (C) 2021 Author(s) retain the copyright of this article. This article is published under the terms of the Creative Commons Attribution Liscense 4.0.
} 
attributes had impact on earnings quality of firms. It becomes imperative to examine these with external audit attribute as they influence earnings quality of corporate firms.

The recent audit failures that swept across the world somewhat recently made users of audited financial reports to give occasion of doubt about the reliability of earnings declared by firms and the ability of auditors to successfully abridge the management sub-optimal behaviour (Dabor and Dabor 2015). The reported instances of failure of some financial institutions have made earnings quality a significant worry among financial experts. The most germane argument of these contentions is that auditors have tasks to carry out in improving earnings quality. Numerous studies on earnings quality employ diverse earnings quality measures. For instance, Dechow and Schrand (2004) describe earnings quality as a measure of how well earnings mirror the actual performance of a firm. Francis et al. (2004) also argue that there are seven attributes of earnings, such as accruals quality, persistence, predictability, smoothness, value relevance, timeliness, and conservatism, and examine their relationship with the cost of equity capital.

Studies in the area of financial reporting quality (Dechow and Schrand, 2004: Oladejo, et al. 2020: Francis et al. 2004) indicates the significance of corporate attributes and external audit quality as a significant determinant of earning quality. Corporate board attributes have been identified in the literature to include board size, board independence, gender diversity and board meetings and have produced mixed results on relationship with earnings quality of firms. For instance, Oladejo et al, (2020) observed that the primary constituent of an organization is the board of directors due to their monitoring roles over the financial reports of the organization as well as carrying out other duties assigned to them by the owners. Managers often tend to act in their sole interest to smooth earnings causing misinformation to the owner and other stakeholders, this necessitate the monitoring role of the board on the financial statements prepared by managers. In another study, Kajola, (2020) argued that the behaviour of managers in involving in earnings management can be attributed to the separation of ownership and control couple with need to produce and report financial statements that shows that they perform better in the reporting year. Therefore a good governance structure should be able to monitor and curtail opportunistic tendency of managers. When the board is well composed with mostly non-executive independent directors and there is board independence it is believed that managers will have lesser opportunity to manipulate earnings. Therefore earnings quality is enhanced with effective corporate board as observed by Mahrani and Soewarno (2018) that good corporate governance is a major requirement for effective and efficient running of organisations like banks for the achievement of depositors' confidence and equal treatment of all stakeholders. Exploring these corporate board attributes with audit firms characteristics is expected to provide empirical evidence on earnings quality of corporate firms in Nigeria.

Existing studies agreed on the influence of the presence of audit firms on the earnings quality of corporate organizations. For instance, Cascino et al. (2010) using a sample of listed family firms, show that the presence of a renowned audit firm increases earnings quality. The common auditor characteristics of significance as identified in the literature of accounting and auditing are the size of the audit office, the period of customer retention, the audit office link with global auditing offices, specializing in the customer's industry, audit fees. Others are audit firm market concentration, auditor independence and mandatory rotation of auditors (Olowookere \& Olowookere, 2013; TawfiqShibli, Ibrahim Saleh, \& Abdul Rahman, 2019; Oladejo, Olowookere \&Yinus, 2020; Soyemi \& Olawale, 2020).

As asserted by Alzoubi (2016), extant studies examining the relationship between audit quality and earnings management, have been mostly based on developed economies, while studies based on developing economies are still limited. The extent of influence board attributes can exert on earnings quality is worthy of exploration in a developing economy, especially in the Nigeria food and beverages producing firms., Nigeria's food and beverages industry is a component of the manufacturing sector, which contributed 13 percent or N4.2 trillion to the country's gross domestic product (GDP in current prices) in 2014 (2013: 11 percent or N3.8 trillion). The sector has a unique role in expanding economic opportunity because it is universal to human life and health. The manufacturing sector and particularly the food and beverage sub-sector remain crucial to every economy of the world and the realities in Nigeria are not different.

\subsection{Statement of the problem}

Evidence from the literature show that insincerity in financial reporting raises serious concern not only in USA, Italy and New Zealand but also in Nigeria where the world over witnessed the celebrated collapse of giant companies such as WorldCom, Enron (USA), Parmalat (Italy), Nationwide finance (New Zealand), (Demakis, 2011; Norwani et al, 2011; Lianne, 2011). A good auditing practice is important to support well-working of the reporting system (Paulson 2007). Yet, the collapse of organizations as referenced earlier, which recorded brilliant earnings growth in their audited financial statements made questions over the quality of audit performed. Most studies argued earnings quality from the perspectives of external audit attributes. Few that discussed corporate board attributes were either approached as separate attributes of earnings quality or not in Foods and beverages industry that are reported to have greater 
contribution to the Nigerian economy. In this regard, further empirical evidence is required to address the fundamental issues as how corporate board and external audit attributes influence earnings quality of listed foods and beverages firms in Nigeria which is constitute the gaps to be filled by the current study.

\subsection{Research Hypothesis}

$\mathrm{H}^{1}$ : There is no significant variation in the determinants of corporate board and external audit attributes of listed foods and beverages firms in Nigeria.

$\mathrm{H}^{2}$ : Corporate board and external audit attributes have no significant influence on the earnings quality of listed foods and beverages firms in Nigeria.

\section{Literature Review and Conceptual Explanation}

\subsection{Concept of Corporate Board Attributes}

Corporate board attributes is a corporate governance part that describe the effectiveness of a board to supervise and monitor the management of a corporate firms for better performance. Studies have shown four corporate board attributes as influencing earnings quality of firms to be board size, board independence, gender and experience of board members (Al-Balqaa\& Al-Balqaa, 2019; Soyemi, et al , 2020, Kajola, et al , 2020,. For example, Al-Balqaa\& Al-Balqaa, (2019) found that there is a statistically significant impact from board characteristics on earnings quality, for instance the board size and the experience of board members have a positive and significant impact on earnings quality, while duality has a negative significant impact on earnings quality. The other characteristics, board independence, the qualification of board members and the gender of board members, had no significant impact on earnings quality. Further, the level of corporate governance can be measured by the existence of an audit committee, separation of the duties of the chairman and chief executive officer (Tsui et al., 2001), and the number of nonexecutive directors, board size and board independence (Kao and Chen, 2004; Asogwa, Ofoegbu, Nnam, Chukwunwike \& Ntim, 2019; Kajola, et al. 2020; Oladejo, 2019).

\subsubsection{Board Independence}

According to Kelton and Yang (2008), the capacity of the board to execute its monitoring role relies upon its independence from management and thus independent boards have a greater capacity to limit managerial opportunistic behavior and reduce managements' ability to withhold information. The majority of research examining the association between board independence and Earning Management generally supports the importance of board independence in monitoring Earning Management practices. In the US context, Klein (2002) reports a negative relationship between Earning Management and the percentage of independent directors. Moreover, Niu (2006) provides evidence supportive of the negative association between levels of board independence and Earning Management in Canada. Similar findings are also documented in non-Anglo-Saxon countries, such as in Greece by Dimitropoulos and Asteriou (2010), in India by Rajpal (2012) and in Taiwan by Lee (2013).

\subsubsection{Board Size}

The size of the board is expected to affect the discretionary accruals and improve the financial reporting quality due to the higher degree of inspection and monitoring by the board of directors. A larger board consists of more number of directors who work towards the interest of the stakeholders in monitoring and controlling, and thereby increasing the firm performance. Thus agency theory believes that larger board size enhances the firm performance by better monitoring by a large group of people. Mashayekhi and Bazaz (2008) found evidence that a larger board size makes monitoring less efficient because corporate communication will be less efficient, which translates into inadequate accounting information. Ismail (2011) discovered that board size is positively associated with nonfamily firms and negatively associated with the board size. Talbi et al. (2015) study investigated the effectiveness of board characteristics in limiting earnings management. Empirical results depicted the positive impact of board size on earnings management.

\subsubsection{Audit committee Presence}

The audit committee generally reviews earnings releases, SEC filings containing financial information, and other financial information and earnings guidance provided to analysts, ratings agencies, and others. The committee should consider how it will execute these responsibilities to satisfy itself that all information is presented fairly and in a transparent manner. This should include a focus on consistency of information, tone, and messaging across all financial communications. The audit committee should confirm that an appropriate legal review has been completed to verify the completeness of disclosures, including any obligation to report on trends. This legal review should also consider 
compliance with the company's policies on forward-looking statements and the completeness of any related disclaimers.

An audit committee according to Dare, Efuntade, Alli-Momoh and Efuntade (2021), is a committee of an organization's board of directors which is responsible for oversight of the financial reporting process, selection of independent auditor and receipt of both internal and external audit results. According to Ahmed (2018), audit committee referred to a group of people selected from members of the board of directors who are responsible for retraining the independence of auditors. An audit committee assists the board of directors to fulfil its corporate governance and overseeing responsibilities in relation to an entity's financial reporting, internal control system, and risk management system as well as its internal and external audit functions (Dabor \& Dabor, 2013). Its role is to provide advice and recommendations to the board within the scope of its terms of reference.Hutchinson, Percy, and Erkurtoglu (2008) used the Australian sample and found that board independence and audit committee independence negatively influenced performance-adjusted discretionary accruals.

\subsection{External Audit Attributes}

This comprises of all external audit features that determine quality reporting practice

\subsubsection{Audit Firm Size}

Audit Firm Size describes whether an audit firm is big or small as a measure of capability for independent audit work. It was argued that audit firm size does not affect audit quality because all firms adopt uniform professional standards irrespective of the size. However, DeAngelo (1981) argued that with all other factors being constant, size alone affects auditor's incentives to act opportunistically. Hence, larger audit firms provide a higher level of audit quality as they have 'more to lose'. According to the results of the study conducted by (Al-khaddash, Nawas and Ramadan 2013), there is a significant positive correlation between audit quality and the reputation of the audit firm and the size of the audit firm. This justifies the ground of using auditor size as a proxy to represent audit quality. Specifically, Chu et al. (2014) considered the effect of the size of clients and audit firms on the level of competition and concluded that when the size of a client increases, some small audit firms in the market may not be potentially efficient suppliers to the client due to the high transaction costs associated with their limited production capacity.

\subsubsection{Auditor Independence}

The probability of detection to auditor competence and probability of revelation is associated with auditor independence as large accounting firms have created trade mark to keep their reputations and have also maintained their reputations by delivery of high-quality audit (Dabor \& Dabor 2015). They claimed that lack of financial affiliation with clients makes bigger auditors more independent. This independence provides large auditors with stronger negotiation stance compared with smaller audit firms. Other prior studies have shown that auditor independence affects earnings quality positively. According to Hayes et.al (2004) and BahramSoltani (2007), auditor independence refers to the auditor's ability to maintain an objective and impartial mental attitude throughout the audit. This is influenced by audit fees, audit tenure, and audit regulations (Nelson, Elliott \&Tarpley, 2002).

\subsubsection{Company Size}

Evidence from the literature of accounting and audit showed that the size of firms have the strong effect on the earning management of the firms. Moreover the study also showed that the firms that are small in size manage their earning less than the firms that are large in size. The firm size may have a positive impact on earnings management. Larger companies may have more sophisticated internal control systems and have more competent internal auditors as compared to smaller companies. Therefore, larger firms are more likely to design and maintain more sophisticated and effective internal control systems in comparison to smaller firms, reducing the likelihood of manipulating earnings by management.

\subsection{Audit Quality}

Audit quality has been regarded a complex subject with no universal definition or analysis. Authors agreed that a quality audit is likely to be achieved when the auditor's opinion on the financial statements can be relied upon as it was based on sufficient appropriate audit evidence obtained by an engagement team that exhibited appropriate values, ethics and attitudes; was sufficiently knowledgeable and experienced and had sufficient time allocated to perform the audit work; applied a rigorous audit process and quality control procedures; provided valuable and timely reports; and interacted appropriately with a variety of different stakeholders. Riley (2001) observed that audit quality is multidimensional and inherently unobservable, and that there is no single auditor characteristic that can be used as a proxy for it. In the 
absence of direct measures for quality, Riley (2001) suggests that audit consumers must assess the quality by using surrogates, or the overall reputation of an auditor.

\subsection{Earnings Quality}

Earnings quality has various definitions since it comprises of different characteristics. An unambiguous, by and large acknowledged meaning of earnings quality and estimation is believed not existing, making it a dicey idea (Revsine et al., 2001, Penman and Zhang, 2002). Numerous examinations on earnings quality utilize diverse earnings quality measures. Schipper and Vincent (2003) conclude earnings quality from the hypothesis of monetary compensation. Dechow and Schrand (2010) characterize earnings quality as a proportion of how well earnings mirror the genuine performance of a firm.

\subsection{Economic Importance of Foods and Beverages Sector}

The manufacturing sector and particularly the food and beverage sub-sector remain crucial to every economy of the world and the realities in Nigeria are not different. In recent years, the performance and contribution of these category players to the Nigerian economy has grown in value and relevance (Ayodeji, 2020). According to Ishau, (2017) Nigeria's food and beverages industry is a component of the manufacturing sector, which contributed 13 percent or N4.2 trillion to the country's gross domestic product (GDP in current prices) in 2014 (2013: 11 percent or N3.8 trillion). Several manufacturing sectors like the Food and Beverage, Textile sector, Paper and Paper Products, Chemical and Pharmaceutical products, Plastic and Rubber Products, Weed and Wood Products grew as more indigenous and foreign players invested to meet local demand. Amongst the sectors that have witnessed tremendous growth since then has been the Food and Beverage sector. Accord to EUMERCI Horrizon Project Report (2020), the food and beverage industry is the manufacturing industry that contributes most to the national economy, both in terms of turnover and Gross Value Added (GVA). Despite the crisis and in contrast to the national manufacturing industry, the national food and beverage industry grew between 2013 and 2016 in terms of number of companies and Gross Value Added.

\subsection{Empirical Review}

Scholars have explored the effect of corporate governance mechanisms on ensuring earnings quality and sound financial performance from diverse dimensions (Aref \& Nejat, 2012; Asogwa, et al, 2019), only limited studies have focused on the effect of board leadership models and attributes on earnings quality For example, Jouber and Fakhfakh (2014) focused on CEO duality incentive-based compensation corporate governance mechanisms and earnings management and conclude that shareholder protection plays a critical role in ensuring accrual quality. Idris, Abu Siam, and Nassar, (2018) examined the moderating effect of family ownership over the relationship between board independence and earnings management. Using information of industrial companies indexed on Amman Stock Exchange, this research provides evidence of negative relationship between board independence and earnings management, proposing that higher percentage of board independence is related with more effective monitoring to reduce earnings management. Moreover, the results document that the relationship between board independence and earnings management becomes weak when there is an interaction with family ownership control. These outcomes indicate that an increase in the percentage of independent directors to mitigate earnings management is less likely to be influential in the case of family controlled firms. Oladejo , (2020) evaluated the effect of board attributes on earnings on earnings quality of listed financial firms in Nigeria. The study employed secondary data. Soyemi and Olawale, (2019) investigated firm's characteristics effect on financial reporting quality of Nigerian quoted manufacturing companies. Twenty-five (25) nonfinancial companies from 2009 to 2016 were used as sample, findings revealed firm size and profitability have significant positive influence on quality of financial reporting, while tangibility and firm growth were documented to have significant but negative influence on quality of financial reporting. More so, different studies approached the relationship between external audit attributes and earnings quality in different ways and from different continents with mixed results. For instance, Lopes (2018) in Portugal examined the relationship between audit quality and earnings management using 4723 Portuguese non-listed firms.The results suggest that there is a relationship between audit quality and earnings manipulation. Also, Pakianathan (2017) studied the impact of audit quality on earnings management in public listed entities in Sri Lanka. Using panel data analysis, the study concluded that audit quality exerts no significant impact on the degree of earnings management. Maletta, (2010) investigated the impact of inherent risk on auditors' decisions to use internal auditors as assistants. The results indicate that inherent risk impacts the extent to which internal audit objectivity and work performed affect auditors' decisions to use internal auditors as assistants.

The current study contributes to the literature of accounting and auditing by examining the effect of board attributes on the earnings quality of listed foods and beverages firms in Nigeria. The study examines how models of unitary and bi-leadership structures under different professional and innate attributes of board leaders influence the earnings quality of the sampled firm. Also the construct of this study was based on Agency Theory (AT) and Lending Credibility 
Theory (LCT). Adoption of AT is based on the fact that Audit serves a fundamental purpose in promoting confidence and reinforcing trust in financial information and agency theory is a useful economic theory of accountability that helps to explain the development of the audit practice. More so, lending credibility theory focus on the primary function of the audit as to add credibility to the financial statements. In this view the service that the auditors are selling to the clients is credibility. Audited financial statements are seen to have elements that increase the financial statement users' confidence in the figures presented by the management in the financial statement.

\section{Methodology}

The research population comprises of all the twenty three (23) foods and beverages companies listed on the Nigerian Stock Exchange (NSE) as at 31 ${ }^{\text {st }}$ December 2019, out of which 8 were selected for the purpose of the .Secondary data were employed through audited annual reports and accounts of eight (8) selected foods and beverages firms listed on the Nigerian Stock Exchange using judgmental sampling technique. Data collected were analyse using descriptive statistics like table, and inferential statistics such as panel regression analysis.

\subsection{Model Specification}

\subsubsection{Earnings Quality Model}

Panel Regression model was employed. The dependent variable is earnings quality and measured using discretionary accruals (DACC) as specified by the modified jones model (1995). In order to estimate DACC model, there is need to calculate total accruals (TAC).

TACit $=$ EBXIit - CFOit

Where

TACit = Total accruals for company ïn year $t$.

EBXIit = Earnings Before Extraordinary Items of company $\mathrm{i}$ in year $\mathrm{t}$

CFOit $=$ Net cash flow from operations of company ifor year $t$.

TACit $=\alpha_{1} \_1+\alpha_{2}\left(\Delta \operatorname{Rev}_{i t}-\Delta \operatorname{Rec}_{i t}\right)+\alpha_{3}\left(\mathrm{PPE}_{\mathrm{it}}\right)+\varepsilon_{i t}$

(TAit-1)

NDAC $_{i t}=\alpha_{1} \ldots 1+\alpha_{2}\left(\Delta \operatorname{Rev}_{i t}-\Delta \operatorname{Rec}_{i t}\right)+\alpha_{3}\left(\right.$ PPE $\left._{i t}\right)+\varepsilon_{i t} \ldots$

$\left(\mathbf{T A}_{i t}-\mathbf{1}\right)\left(\mathbf{T A}_{i t}-\mathbf{1}\right)$

Where,

$\Delta$ Revit= Change in revenue for company ïn year $t$.

$\Delta$ Recit $=$ Change in receivables for company ïn year $t$.

PPEit $=$ Net property, plant and equipment for company ïn year $t$.

TAit-1= Total assets for firm ïn year $t-1$.

$\operatorname{DACC}_{i t}=$ TACC $_{i t}-$ NDAC $_{i t}$

DACC $_{i t}=\beta_{0}+\beta_{1}\left(\right.$ AuSizit $\left._{i t}\right)+\beta_{2}\left(\right.$ AuInd $\left._{i t}\right)+\beta_{3}\left(\right.$ AucP $\left._{i t}\right)+\beta_{4}\left(B_{z_{i t}}\right)+\beta_{5}\left(\right.$ BInd $\left._{i t}\right)+\beta_{6}(C S z i t)+\varepsilon_{i t}-(3.5)$ 
Table 1 Description and Measurement of Variables

\begin{tabular}{|c|c|l|}
\hline Variable & Abbreviation & \multicolumn{1}{|c|}{ Measurement } \\
\hline $\begin{array}{c}\text { Discretionary Accruals } \\
\text { (Abs) }\end{array}$ & DACCit & $\begin{array}{l}\text { discretionary accruals of company ifor year t using modified Jones } \\
\text { model (scaled by lagged total assets) }\end{array}$ \\
\hline Audit firm size & AuFSit & "1" if firm's auditor is a member of Big 4, "0" otherwise. \\
\hline Audit Independence & AudIndit & Natural logarithm of audit fees of firm ifor year t \\
\hline $\begin{array}{c}\text { Audit Committee } \\
\text { Presence }\end{array}$ & AucPit & "1" if company has an audit committee, "0" otherwise. \\
\hline $\begin{array}{c}\text { Board size } \\
\text { Board independence }\end{array}$ & BSzit & Firms i total number of board members for year t. \\
\hline $\begin{array}{c}\text { Company Size } \\
\text { CSzit }\end{array}$ & No. of independent non-executive chairman \\
\hline $\begin{array}{c}\text { Cash flow from } \\
\text { operations }\end{array}$ & CFOit-1 & $\begin{array}{l}\text { Net cash flow from operations of company ifor year t divided by Total } \\
\text { assets of company ifor year t-1. }\end{array}$ \\
\hline $\begin{array}{c}\text { Return on Assets } \\
\text { ROAit }\end{array}$ & $\begin{array}{l}\text { Profit before interest and tax of company ifor year t divided by Total } \\
\text { assets of company ifor year t. }\end{array}$ \\
\hline
\end{tabular}

\section{Results and discussion}

\subsection{Descriptive Statistics of the study Variables}

The corporate board, external audit attributes and earnings quality variables alongside the moderating and control variables were analysed using descriptive statistics in order to provide general characteristics of the sample as presented in table 2. Analysis from table 2.indicates that the absolute value of discretionary accruals (AbsDACC) has a mean value of 0.169 with a maximum of 0.511 and a minimum value of 0.000 . The mean value of $16.9 \%$ revealed that the degree at which earnings are managed in the sample firms is cautiously significant. Regarding audit attributes proxies, it is obvious that $81 \%$ of the sample firms (mean value of 0.812 ) are being audit by the big four audit firms in Nigeria. The higher proportion could be as a result of perceived sophisticated audit quality of the big audit firms as this would enhance the credibility of the companies' financial statement hence greater earning quality. Further, audit independence (AuInd) reports a mean of 26544 with a standard deviation of 12001 . This means that there is a significant variation in terms of audit fees within the sample size. Also, the mean value of 0.949 for audit committee presence (ACPres) imply that almost all firms (94\%) of sampled firms have an audit committee. On the other hand, company size (CSz) which was measured using natural logarithm of firms' total assets have a mean value of 17.635 within the range of 19.0 to 14.2. This means that the average size of the sampled firms in terms of total assets is approximately $\$ 33$ trillion with a minimum of $\$ 14$ trillion and a maximum of $\$ 56$ trillion. Furthermore, the companies within the sample operate with an average of nine (9) directors in the board with maximum and minimum of 11 and four directors respectively.

On the part of board independence, three (3) members are independent non-executive directors on average with maximum being 5 and 0 as some of the sample had no independent non-executive directors in their board composition. The firms' generated positive cash flow from operations with a mean value of $23 \%$ relative to its total assets. This indicate good performance in terms of higher cash flow generation. Nevertheless, the average performance of the companies as reported by return on assets (ROA) is $20 \%$ while some reported $91 \%$. More so, skewness and kurtosis reveals the normality of the variables. Pakianathan (2017) reported that if skewness is within the range of \pm 1.96 and kurtosis within \pm 2 , then the data is said to be normally distributed. As shown in table 2, AudInd, AuFS, CSz, BInd and BSz satisfied skewness condition while none of the variables satisfied kurtosis. Pakianathan (2017) however asserted in his study that where earnings quality is the dependent variable, non-normality in variables can be expected. 
Table 2 Descriptive Statistics of the Study Variables

\begin{tabular}{|l|c|c|c|c|c|c|c|}
\hline Variables & Mean & Min. & Max & S.D. & Median & Skewness & Kurtosis \\
\hline AbsDACC & 0.169 & 0.000 & 0.511 & 0.182 & 0.119 & 2.370 & 10.640 \\
\hline AuInd & 26544 & 4900 & 53000 & 12001 & 26000 & 0.375 & 2.376 \\
\hline AuFs & 0.8125 & 0.000 & 1.000 & 0.393 & 1.000 & -1.601 & 3.564 \\
\hline CSz & 17.635 & 14.199 & 19.000 & 0.945 & 17.813 & -0.944 & 4.436 \\
\hline Bind & 3.163 & 0.000 & 5.000 & 1.326 & 3.000 & -0.071 & 2.370 \\
\hline CFO & 0.813 & 0.002 & 0.496 & 0.394 & 0.134 & 5.609 & 38.305 \\
\hline BSz & 8.875 & 4.000 & 11.000 & 1.470 & 9.000 & -0.865 & 4.906 \\
\hline ROA & 20.000 & -0.297 & 0.909 & 0.283 & 0.148 & 3.309 & 16.590 \\
\hline ACPres & 0.949 & 0.000 & 1.000 & 0.221 & 1.000 & -4.099 & 17.803 \\
\hline
\end{tabular}

\subsection{Regression Result to Identify and Evaluate the Determinants of Corporate Board and External Audit Attributes of Foods and Beverages Firms in Nigeria}

Table 3 show results of determinants of corporate board and external audit attributes. Analysis from table 3 revealed that board size (BSz), audit committee presence (AucP), company size (Cz) audit firm size (AFS) are the significant determinants of corporate board and external audit attributes of the selected foods and beverages firms in Nigeria. Also, the adjusted $\mathrm{R}^{2}$ of 0.5624 indicate that explanatory variables are accounted for $56 \%$ variation in dependent variable. The F-statistics of 21.05 and F-probability of 0.0000 confirms the significant of the entire model.

Table 3 Regression Result on Evaluation of the Determinants of Corporate Board and External Audit Attributes of Foods and Beverages Firms in Nigeria

\begin{tabular}{|c|c|c|c|c|c|c|}
\hline $\begin{array}{c}\text { Dependent } \\
\text { Variables }\end{array}$ & $\begin{array}{c}\text { Independent } \\
\text { Variables }\end{array}$ & Coefficient & Standard Error & $\mathbf{T}$ & P>/T/ & (95\%Conf. Interval) \\
\hline CBEAA & BSz & $-2741.887-$ & 655.1979 & -4.18 & 0.000 & $4047.694-1436.079$ \\
\cline { 2 - 7 } & BInd & 598.9642 & 763.1162 & 0.78 & 0.435 & -921.92422119 .853 \\
\cline { 2 - 7 } & ACPres & $-8225.106-$ & 4021.661 & -2.05 & 0.044 & $16240.27-209.946$ \\
\cline { 2 - 7 } & CSz & 5454.197 & 961.5581 & 5.67 & 0.000 & 3537.8147370 .579 \\
\cline { 2 - 7 } & AFS & 14485.32 & 2385.727 & 6.07 & 0.000 & 9730.57619240 .07 \\
\cline { 2 - 7 } & Constant & $51393.47-$ & 17849.33 & -2.88 & 0.005 & $-86967.13-15819.81$ \\
\cline { 2 - 7 } & F(5,73) & $\begin{array}{c}0.5624 \\
21.05\end{array}$ & & & & \\
\hline
\end{tabular}

Source: Researcher's Computation (2021)

\subsection{Effect of Corporate Board and Audit Attributes on Earnings Quality of Foods and Beverages of Listed Manufacturing Firms in Nigeria}

Analysis in table 4 presents the result of model 2 for objective where the dependent variable is the absolute discretionary accruals. The R-Square of 57\% indicates that the independent variables could only explain $57 \%$ variation in dependent variable AbsDACC. Also, the Wald chi2 of 121.4 and Prob $>$ chi2 $=0.0077$ confirm that there is joint significant between the dependent and the independent variables. From the table 4.6, there is statistically significant relationship between audit independence and the absolute value of discretionary accruals. This implication of this that auditors' independence improves earnings quality because when the auditors become independence, management is compelled to eschew earnings manipulation. The result contradicts the findings of Pakianathan (2017). The study also 
found a statistical significance negative relationship between audit firm size and absolute discretionary accruals. This is tandem with Alves, (2013) but contradicts Yasar (2013) and Chinget. al. (2015). Board Size reports a negative insignificant relationship with absolute discretionary accruals. This means that increasing the number of members of the board does not necessarily reduce the degree of discretionary accruals. This is line with the results of Alves (2013). Board independence also reports an insignificant positive association with discretionary accruals. This means that boards may contain less effective independent directors and they are ineffective in restricting discretionary accruals in sampled listed foods and beverages in Nigeria. The study is consistent with the findings of Pakianathan (2017). Furthermore, there exist a negative but insignificant relationship between company size and absolute discretionary accruals. This means that as company size becomes bigger, the magnitude of earnings management reduces thereby increasing earnings quality. More so, the results reveal a positive but insignificant relationship between return on assets and absolute value of discretionary accruals.

Table 4 Panel Regression Result of Effect of Corporate Board and Audit Attributes on Earnings Quality of Foods and Beverages of Listed Manufacturing Firms in Nigeria

\begin{tabular}{|c|c|c|c|c|c|c|}
\hline $\begin{array}{c}\text { Dependent } \\
\text { Variables }\end{array}$ & $\begin{array}{c}\text { Independent } \\
\text { Variables }\end{array}$ & Coefficient & Standard Error & $\mathbf{T}$ & $\mathrm{P}>/ \mathrm{T} /$ & (95\% Conf. Interval \\
\hline \multirow[t]{10}{*}{ AbsDACC } & AudInd & $-6.57 e-06$ & $3.11 \mathrm{e}-06$ & -2.11 & 0.035 & $-.0000127-4.77 \mathrm{e}-0$ \\
\hline & AFS & 0.1141479 & 0.0729972 & 2.56 & 0.018 & -.02892410 .257219 \\
\hline & $\mathrm{BSz}$ & -0.0250654 & 0.0179297 & -1.40 & 0.162 & -.06020690 .0100761 \\
\hline & Bind & 0.0022103 & 0.0185083 & 0.12 & 0.905 & -.03406520.0384859 \\
\hline & ACPres & .0336968 & 0.0984304 & 0.34 & 0.732 & -.1592234 .2266169 \\
\hline & $\mathrm{CSz}$ & -0.0116558 & 0.035141 & -0.33 & 0.740 & -.08053090 .0572192 \\
\hline & Constant & 0.6291536 & 0.6034875 & 1.04 & 0.297 & -.55366011 .811967 \\
\hline & $\mathrm{R}^{2}$ & 0.5725 & & & & \\
\hline & Wald Chi2 & 121.4 & & & & \\
\hline & Prob $>$ Chi 2 & 0.0077 & & & & \\
\hline
\end{tabular}

\section{Conclusion}

Emphasis on earnings management has increased considerably, since the fall of well-known corporates owing to scandals. Following the outcome of the analysis, The study concluded that corporate board attributes (audit committee) and external audit attributes (auditor independence, audit firm size) had significant effect on earnings quality as measured by earnings management of selected foods and beverages firms in Nigeria. The study recommends that in order to enhance auditor's independence, uniform audit fee should be formulated, and also, disclosure should be made on other corporate board attributes like board members' year of experience and gender and for effective monitoring system.

\section{Compliance with ethical standards}

\section{Acknowledgments}

We thank all the anonymous referees for their useful suggestions.

\section{Disclosure of conflict of interest}

No conflict of Interest. 


\section{References}

[1] Al-Khaddash H, Al Nawas R, Ramadan A. Factors Affecting the Quality of Auditing: The Case of Jordanian Commercial Banks. International Journal of Business and Social Science. 2013; 4(11).

[2] Alves S. The impact of audit committee existence and external audit on earnings management: Evidence from Portugal. Journal of Financial Reporting \& Accounting. 2013; 11(2): 143-165.

[3] Alzoubi E. Ownership Structure and Earnings Management: Evidence from Jordan. International Journal of Accounting \& Information Management. 2016; 24(2): 135-144.

[4] Asogwa CI, Ofoegbu GN, Nnam JI, Chukwunwike, Ntim CG. Effect of Corporate Governance Board Leadership Models and Attributes on Earnings Quality of Quoted Nigerian Companies; Cogent Business \& Management. 2019; 6(1).

[5] Ayodeji A. Reinforcing Footprint in Food, Beverage Industry March 20, 2020 12:51 am. THIS DAY NEWS PAPER. 2020.

[6] Baatwah SR, Salleh Z, Stewart J. Audit Committee Chair Accounting Expertise and Audit Report Timeliness: The Moderating Effect Of Chair Characteristics. Asian Review of Accounting. 2019; 27(2): 273-306.

[7] Cascino et al. Understanding Earnings Quality: A Review of the Proxies, Their Determinants and Their Consequences. Journal of Accounting and Economics. 2010; 50(2-3): 344-401.

[8] CED report. Economic Contribution of the Food and Beverage Industry: A Report by the Committee for Economic Development of The Conference Board. 2017.

[9] Ching C Teh, B, San O, Hoe H. The Relationship Among Audit Quality, Earnings Management, and Financial Performance of Malaysian Public Listed Companies. International Journal of Economics and Management. 2015; 9(1): 96-105.

[10] Chu, Wujin, Im, Meeja, Lee, Eun Ju. Investor Expertise as Mastery over Mind: Regulating Loss Affect for Superior Investment Performance. Psychology \& Marketing. 2014.

[11] Dabor E, Dabor A. Auditor Attributes and Earnings Quality in The Nigerian Banking Sector. International Journal of Social and Economic Research. 2015; 9(2): 101-108.

[12] Dare CT, Efuntade AO, Alli-Momoh BO, Efuntade 00. Audit Committee Characteristics and Audit Quality: Exploratory and Empirical Analysis in Nigerian Oil Sector. European Journal of Accounting, Auditing and Finance Research. 2021; 9(1): 97-111.

[13] DeAngelo LE. Auditor Size and Audit Quality. Journal of Accounting and Economics. 1981; 3: 183-199.

[14] Dechow P, I Dichev. The Quality of Accruals and Earnings: The Role of Accrual Estimation Errors. The Accounting Review (Supplement). 2002; 77(5): 35-59.

[15] Dechow P, Ge W, Schrand C. Understanding Earnings Quality: A Review Of The Proxies, And Their Determinants And Their Consequences. Journal of Accounting amd Economics. 2010; 50: 344-401.

[16] Dechow PM, Sloan, Sweeney AP. Detecting Earnings Management. The Accounting Review. 1995; 70: 193-225.

[17] Demirkan S, Platt H. Financial Status, Corporate Governance Quality, And The Likelihood Of Managers Using Discretionary Accruals. Accounting Research Journal. 2009; 22(2): 93-117.

[18] Dimitropoulos, Panagiotis, Asteriou, Dimitrios. The Effect of Board Composition on The Informativeness And Quality of Annual Earnings: Empirical evidence from Greece. Research in International Business and Finance. 2005.

[19] Egbunike CF, Odum AN. Board Leadership Structure and Earnings Quality: Evidence From Quoted Manufacturing Firms in Nigeria. Asian Journal of Accounting Research. 2018; 3(1): 82-111.

[20] EUMERCI. Analysis of Food and Beverage sector in different Countries; HORIZON 2020 Project. 2020.

[21] Francis JR, Wilson ER. Auditor Changes: A Joint Test of Theories Relating to Agency Costs and Auditor Differentiation. Accounting Review. 1988; 63: 663-682.

[22] Hutchinson MR, Percy P, Erkurtoglu L. An investigation of the association between corporate governance, earnings management and the effect of governance reforms. Accounting Research Journal. 2008; 21(3): 239-262. 
[23] Idris M, Abu Siam Y, Nassar M. Board Independence, Earnings Management and the Moderating Effect of Family Ownership in Jordan; Management \& Marketing: Challenges for the Knowledge Society. 2018.

[24] Ishau L. The Growth and Impact of the Nigerian Food and Beverage Sector. 8 July 2007.

[25] Ismael HR, Roberts C. Factors affecting the Voluntary use of Internal Audit: Evidence from the UK. Managerial Auditing Journal, Issue(s) available. 2018; 1(1): 35(6).

[26] Ismail WABW. Earnings quality, family influence and corporate governance; Empirical evidence from Malaysia. PhD Thesis; Victoria University of Wellington. 2011.

[27] Kajola SO, Sanyaolu WA, Tonade AA, Adeyemi A. Corporate board attributes and earnings management in Nigerian banking sector. Journal of Sustainable Development in Africa. 2020; 22(4) ISSN: 1520-5509.

[28] Kao L, Chen A. The Effects of Board Characteristics on Earnings Management; Corporate Ownership \& Control. International Journal of Accounting and Finance. 2004; 1(3): 96 -107.

[29] Klai N, Omri A. The governance role of the financial information: Empirical evidence in the Tunisian context. AfroAsian Journal of Accounting and Finance. 2011; 2(4): 283-298.

[30] Klein A. Audit Committee, Board of Director Characteristics, and Earnings Management, Journal of Accounting and Economics. 2002; 33(3): 375-401.

[31] Lee Y. Can Independent Directors Improve the Quality of Earnings? Evidence from Taiwan. Advances in Management and Applied Economics. 2013; 3(3): 45-66.

[32] Liu J, Harris K, Omar N. Board Committees and Earnings management. Corporate Board: Role Duties \& Composition. 2013; 9(1): 6-17.

[33] Ljubisavljević S, Jovanovi D. Empirical Research on the Internal Audit Position of Companies in Serbia. Journal of Economic. 2011; 19(1): 123-141.

[34] Lopes. Audit Quality and Earnings Management: Evidence from Portugal. Athens Journal of Business \& Economics. 2018; 4(2): 179-192.

[35] Mahrani M, Soewarno N. The Effect of Good Corporate Governance Mechanism and Corporate Social Responsibility on Financial Performance with Earnings Management as Mediating Variable", Asian Journal of Accounting Research. 2018; 3(1): 41-60.

[36] Maletta MJ. An Examination of Auditors' Decisions to Use Internal Auditors as Assistants: The Effect of Inherent Risk; Contemporary Accounting Research. 2015; 9(2): 508 - 525.

[37] Nelson, Mark, Elliott, John, Tarpley, Robin. Evidence from Auditors about Managers' and Auditors' Earnings Management Decisions. The Accounting Review. 2002; 77(4).

[38] Nelson P, Davis S. Audit Committee Experts and Earnings Quality: Corporate Governance. The International Journal of Business in Society. 2013; 13(4): 335-351.

[39] Niu F. Corporate Governance and the Quality of Accounting Earnings: A Canadian Perspective. International Journal of Managerial Finance. 2006; 2(4): 302-327.

[40] Norwani NM, Zam ZM, Chek IT. Corporate governance failure and its impact on financial reporting within chosen companies. International Journal of Business and Social Science. 2011; 2(21).

[41] Nwaobia AN, Ogundajo GO, Theogene N. Internal Audit Practices and Public Financial Management in Rwanda and Nigeria: Bridging the Transparency Gap in Public Sector Financial Reporting. International Journal of Advanced Academic Research | Social \& Management Sciences. 2016; 2(10): 503-513.

[42] OECD. OECD principle of corporate governance. OECD Publications No. 80411, 2 rue Andre-Pascal Paris CREDEX 16.

[43] Oladejo AO. Board Attributes and Earnings Quality of Listed Financial Firms in Nigeria; Sumerianz. Journal of Business Management and Marketing. 3(5): 38-45. 2020.

[44] Oladejo M, Yinus S0, Shittu S, Rutaro A. Internal audit practice and financial reporting quality: Perspective from Nigerian quoted foods and beverages firms. KIU Interdisciplinary Journal of Humanities and Social Sciences. 2(1): 410-428.2021.

[45] Oladejo MO, Yinus SO, Olowookere JK. External Audit Quality and Users Confidence in Financial Reports: Evidence from Nigerian Deposit Money Banks.International Journal of Technology and Management. 5(1). 2020. 
[46] Olowokure OA Tanko M, Nyor T. Firm structural characteristics and financial reporting quality of listed deposit money banks in Nigeria. International Business Research. 2016; 9(1): 106- 122.

[47] Pakianathan AE. Audit Quality and its Impact on the Degree of Earnings Management: Evidence from Sri Lanka.University of Sri Jayewardenepura Nugegoda. 2017.

[48] Poltak H. Sudarma M, Purwanti L. The Determinants of the Effectiveness of Internal Audits with Management Support as the Moderating Variable. International Journal of Multicultural and Multireligious Understanding. 2019; 6(1): 33-51.

[49] Rahman M, Rodríguez-Serrano MA, Lambkin M. Corporate Social Responsibility and Marketing Performance: The Moderating Role of Advertising Intensity. Journal of Advertising. 2017; 57(4): 368-378.

[50] Rajpal, Hanish. Independent Directors and Earnings Management - Evidence from India. International Journal of Accounting and Financial Management Research (IJAFMR). 2012; 2(1): 9-24.

[51] Ramesh K, Revsine L. The Effects of Regulatory and Contracting Costs on Banks' Choice of Accounting Method for Other Postretirement Employee Benefits. Journal of Accounting and Economics. 2001; 30(4): 159-186.

[52] Riro GK, Waweru NM, Uliana EO. Quality of Corporate Reporting; Case Studies from an Emerging Capital Market. Afro-Asian Journal of Accounting and Finance. 2016; 6(1): 31-52.

[53] Rokiah I, Noor A, Kamarul B, Abdul Manaf. Firm Characteristics and Financial Reporting Quality: The Moderating Role of Malaysian Corporate Governance Index. The Journal of Social Sciences Research, Academic Research Publishing Group. 2018; 6(2): 924-932.

[54] Roodposhti F, Nabavi C, Seyed A. The Effect of Board Composition and Ownership Concentration on Earnings Management: Evidence from Iran. World Academy of Science, Engineering and Technology. 2010; 66(5): 165171.

[55] Soyemi KA, Olowofela OE, Yunusa LA. Financial Inclusion and Sustainable Development in Nigeria. Journal of Economics \& Management. 39(1): 105-131

[56] Talbi D, Omri M, Guesmi K, Ftiti Z. The role of board characteristics in mitigating management opportunism: The case of real earnings management. The Journal of Applied Business Research. 2015; 31(2): 661-674.

[57] TawfiqShibli AH, Ibrahim Saleh J, Abdul Rahman NG. The Effect of External Audit Quality on Profit Management. International Journal of Accounting. 2019; 35(4): 594-.

[58] Tsipouridou M, Spathis C. Audit Opinion and Earnings Management: Evidence from Greece. Account Forum. 38(1): 38-54.

[59] Tsui, Boo, E, Sharma D. The Association between Corporate Governance and Audit Fees of Bank Holding Companies, Corporate Governance. 8(1): 28-45.

[60] Xie B, Davidson WN, DaDalt PJ. Earnings Management and Corporate Governance: The Role of the Board and the Audit Committee. Journal of Corporate Finance. 9(3): 295-316.

[61] Yasar A. Big Four Auditors Audit Quality and Earnings Management: Evidence from Turkish Stock Market. International Journal of Business and Social Science. 2013; 4(17): 153-163.

\section{Author's Short Biography}

Dr. Yinus S.O. is a professional in the field of learning with a solid research background,
academic experience, and a technology knowledge-based portfolio. He is interested in
developing a career that combines teaching and research. He is an eLearning expert and
lecturer at Kampala International University (KIU) in Uganda, and an E-tutor and lecturer
at the Ladoke Akintola University of Technology Open and Distance Learning Centre in
Nigeria. He has contributed to research through publications in different scholarly
journals in the fields of accounting, finance, business management, entrepreneurship,
and eLearning Development.

